\title{
Modulation of peroxisome proliferator-activated receptor $\delta$ and $\gamma$ transcripts in swine endometrial tissue during early gestation
}

\author{
Etienne Lord, Bruce D Murphy, Joëlle A Desmarais, Sandra Ledoux, \\ Danièle Beaudry ${ }^{1}$ and Marie-France Palin ${ }^{1}$
}

Centre de Recherche en Reproduction Animale, Faculté de Médecine Vétérinaire, Université de Montréal, St-Hyacinthe, Québec, Canada J2S 7C6 and ${ }^{1}$ Dairy and Swine Research and Development Center, Agriculture and Agri-Food Canada, PO Box 90, 2000 Route 108 East, Lennoxville, Quebec, Canada J1M 1Z3

Correspondence should be addressed to M-F Palin; Email: palinmf@agr.gc.ca

\begin{abstract}
Recent evidence points to a role for peroxisome proliferator-activated receptors (PPARs) $\delta$ and $\gamma$ in embryo implantation and survival. In this study, we report the porcine PPAR $\delta$ complete coding sequence and mRNA abundance of PPAR $\delta$, PPAR $\gamma 1$ and $\gamma 2$, angiopoietin-like protein 4 (ANGPTL4) and adipocyte determination and differentiation-dependent factor 1 (ADD1) genes in the pregnant sow endometrium. Real-time PCR analysis was used to study the effect of parity (Yorkshire-Landrace multiparous (YL) and nulliparous (YLn)), site of endometrial tissue sampling (between and at embryo attachment sites) in crossbred Duroc $\times$ Yorkshire-Landrace (DYL) sows and stages of pregnancy (non-pregnant, day 15 and day 25 after mating) in Meishan-Landrace (ML) on mRNA levels. Parity effects were observed for PPAR $\delta$, ANGPTL4, and ADD1, with higher mRNA levels in YL than YLn sows. In DYL sows, lower mRNA levels were present at attachment sites compared to between attachment sites for PPAR $\delta$, PPAR $\gamma 1$, and ANGPTL4. Finally, day 15 pregnant ML sows had lower PPAR $\delta$ mRNA levels compared to day 15 cycling ML sows. A significant increase of PPAR $\gamma 1$ mRNA levels was found on day 25 pregnant ML and DYL sows relative to day $15 \mathrm{ML}$ or DYL pregnant sows. PPAR $\delta$ and $\gamma$ immunostaining was detected in endometrial tissue of day 15 cycling sows, day 15 and 25 pregnant sows and epithelial cells of day 25 embryos. Collectively, our results suggest a role for PPARס, PPAR $\gamma 1$, and ANGPTL4, but not PPAR $\gamma 2$, during the peri-implantation period in pregnant sows.

Reproduction (2006) 131 929-942
\end{abstract}

\section{Introduction}

Peroxisome proliferator-activated receptors (PPARs) are members of the nuclear hormone receptor superfamily of ligand-dependent transcription factors that regulate the expression of target genes involved in cell differentiation and proliferation (Rosen et al. 2000, Michalik et al. 2002). Three subtypes of PPARs, named PPAR $\alpha$, PPAR $\delta / \beta$, and PPAR $\gamma$ (PPAR $\gamma 1$ and $\gamma 2$ ), have been identified in vertebrates, each encoded by a separate gene and fulfilling distinct functions. Whereas the importance of PPARs in the control of lipid and glucose homeostasis and cellular growth and differentiation has been well established, much less is known about their function in reproductive tissues. PPAR $\delta$ is highly expressed in the mouse uterus at implantation sites and its expression requires the presence of an active blastocyst (Lim et al. 1999, Ding et al. 2003b). PPARס was also found in the rat uterus at implantation sites and in decidual cells (Ding et al. 2003a). PPAR $\gamma$ is expressed in human (Marvin et al. 2000), rat (Asami-Miyagishi et al. 2004), and mouse (Barak et al. 1999) placental tissues at various stages of gestation. Studies from knockout mouse models showed that both PPAR $\delta$ and PPAR $\gamma$ have essential, but different roles in murine pregnancy. Indeed, while PPAR $\gamma$ appears to be required for the differentiation of the placenta, PPAR $\delta$ seems to be more important for normal development of the placentaldecidual interface (Barak et al. 1999, 2002). Normal fertility was reported in PPAR $\alpha$ deficient mice, thus suggesting that this nuclear receptor is not essential for normal reproductive function (Lee et al. 1995).

The observation that uterine cyclo-oxygenase-2 (COX-2), a rate limiting enzyme in prostaglandin synthesis, is expressed in an implantation-specific 
manner and that implantation is defective in COX-2deficient mice established that uterine prostaglandins produced by COX-2 may play an essential role in this uterine event (Lim et al. 1997). Moreover, the PPAR $\delta$ selective agonist, L-165041, is able to restore implantation in COX-2-deficient mice, suggesting that COX-2derived prostaglandins mediate embryo implantation via

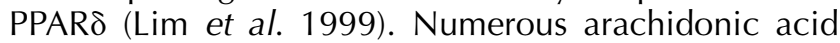
metabolites have been shown to be naturally occurring ligands for nuclear PPARs (reviewed in Helliwell et al. 2004). Prostaglandins are essential during early porcine pregnancy for vascular permeability, placenta development, and immune responses (Geisert et al. 1990), suggesting a key role for PPAR $\gamma$ and $\delta$ in early gestation in pigs. Various genes contain peroxisome proliferator response elements (PPREs) in their upstream regulatory sequences (Martin et al. 1997); however, biologically relevant target genes are largely unknown in reproductive tissues. Angiopoietin-like protein 4 (ANGPTL4) is a PPAR $\gamma$ target gene (Mandard et al. 2004) and, due to its previously reported role as an apoptosis survival factor (Kim et al. 2000) and in angiogenesis (Belanger et al. 2002, Le Jan et al. 2003), it is a relevant PPAR target gene to study in early pregnancy. Therefore, the objectives of this study were (1) to evaluate whether PPAR $\delta, \operatorname{PPAR} \gamma 1$, PPAR $\gamma 2$, and ANGPTL4 are expressed in pig endometrium; (2) to examine the effects of the day of pregnancy (non-pregnant, day 15 and day 25), parity of the sows, and site of endometrial tissue sampling on PPAR $\delta, P P A R \gamma 1, P P A R \gamma 2$, and ANGPTL4 mRNA levels in endometrial tissues. In addition, mRNA levels of ADD1/SREBP1c, a member of the basic helix-loophelix transcription factor family, were also estimated in this experimental design. This last candidate was chosen because of its previously reported role in the production of endogenous ligands for PPAR $\gamma$ (Kim et al. 1998b).

\section{Materials and Methods}

\section{Animals}

Three groups of sows (Table 1) were kindly provided by Genetiporc (St-Bernard, QC, Canada). The first group comprised 22 multiparous Yorkshire-Landrace sows (YL, 4-5 parities) and 22 nulliparous Yorkshire-Landrace sows
(YLn) and was used to study parity effects on transcript abundance of selected genes. The second group consisted of 24 crossbred Duroc $\times$ Yorkshire-Landrace sows (two parities) that were killed on day 15 (DYL15, $n=14$ ) or on day 25 (DYL25, $n=10$ ) of gestation. These sows were used to study the effects of day of pregnancy and site of endometrial tissue sampling (at implantation or between implantation sites). These sows were also used for immunohistochemical analysis. A third group of 24 Meishan-Landrace sows were killed on day 15 (ML15, 2-3 parities) or on day 25 (ML25, 2-3 parities) of gestation, and six Meishan-Landrace sows were killed on day 15 of the estrous cycle (MLc, 2-3 parities). This last group was used to study the effects of pregnancy status (day 15 pregnant vs day 15 of the estrous cycle) and of the day of pregnancy (day 15 vs day 25 pregnant sows). A crossbred sow was also used for tissue distribution analysis. Heat detection was performed twice a day, between 0800 and $0900 \mathrm{~h}$ and between 1600 and $1700 \mathrm{~h}$, by introducing a boar into the pen. At the second estrous, sows were inseminated twice with pooled semen from Landrace boars of proven fertility (CIPQ, Inc., St-Lambert, QC, Canada), 12 and $24 \mathrm{~h}$ after estrus detection. The day of estrus was considered day 0 . All procedures involving animals were approved by the local Animal Care Committee following the guidelines of the Canadian Council on Animal Care (1993).

\section{Tissue collection}

Prior to collection of endometrial tissue, the uteri of day 15 pregnant sows were flushed with PBS and pregnancy confirmed by the presence of embryos in the flushing. The reproductive tract was collected and the uterine horns were opened along the antimesometrial border. Endometrial tissue samples were taken from the mesometrial side, at the sites or between sites of conceptus attachment for the pregnant sows, or in the middle of the horn for the cyclic sows. A minimum of five attachment sites or five endometrial sites were collected for each sow. Attachment sites from day 15 sows were determined by the presence of local hyperemia in endometrial tissue, manifest as a darker reddish color compared to surrounding tissue. All tissue samples were immediately frozen in liquid nitrogen and stored at

Table 1 Description of the population of sows used by breed and distribution in experimental groups.

\begin{tabular}{llcr}
\hline Groups & Breed and parity of sows & $\begin{array}{c}\text { Days of pregnancy (P) or } \\
\text { estrous (E) cycle }\end{array}$ & Sows $(n)$ \\
\hline 1 & Yorkshire-Landrace multiparous (YL) & $\mathrm{Pd} 25$ & 22 \\
& Yorkshire-Landrace nulliparous (YLn) & $\mathrm{Pd} 25$ & 22 \\
2 & Duroc XYorkshire-Landrace multiparous (DYL15) & $\mathrm{Pd} 15$ & 14 \\
& Duroc XYorkshire-Landrace multiparous (DYL25) & $\mathrm{Pd} 25$ & 10 \\
& Meishan-Landrace multiparous (MLC) & $\mathrm{Ed} 15$ & 13 \\
& Meishan-Landrace multiparous (ML15) & $\mathrm{Pd} 15$ & 11 \\
\hline
\end{tabular}


$-80{ }^{\circ} \mathrm{C}$ until processed. The procedure was completed within $20 \mathrm{~min}$ after slaughter. Several tissues were sampled, including liver, kidney, heart, lung, ovary, stomach, brain cortex, endometrium, skeletal muscle, ham subcutaneous fat, back subcutaneous fat, and visceral fat.

\section{RNA extraction and complementary DNA preparation}

Total RNA was extracted from endometrial tissue (minimum of five samples per sows) using TRIzol Reagent (Gibco BRL) according to the manufacturer's instructions. Endometrial RNA samples from individual animals were pooled prior to cDNA synthesis. Total RNA was dissolved in water and quantified spectrophotometrically at $260 \mathrm{~nm}$ and an RNA aliquot was run on 1\% agarose gel to verify its integrity. Total RNA was reverse transcribed to cDNA in a PTC-200 Peltier Programmable Thermal Cycler (MJ Research, Foster City, CA, USA). Five micrograms of total RNA were treated with three units of Dnase I (amplification grade; Gibco BRL) to remove contaminating genomic DNA. First-strand cDNA was synthesised using a SuperScript II preamplification system (Gibco BRL) and $500 \mathrm{ng}$ of oligo(dT) ${ }_{12-18}$ as primer (Amersham Pharmacia Biotech) in a $50 \mu \mathrm{l}$ reaction volume.

\section{Cloning and sequencing of porcine PPARS}

To determine the porcine specific sequence of PPAR $\delta$, degenerate primers (PPARD-F and PPARD-R; Table 2) were designed based on homology between human (GenBank accession no. HUMPPARA), rat (GenBank accession no. U75918), and mouse (GenBank accession no. NM_011145) sequences. PCR amplification was performed under the following conditions: the $50 \mu \mathrm{lPCR}$ reaction contained $200 \mu \mathrm{M}$ dNTPs, $300 \mathrm{nM}$ of each primer, $1.5 \mathrm{mM} \mathrm{MgCl} 2,1$ unit of Taq polymerase (Clontech) in $1 \times$ Taq polymerase buffer. The PCR profile consisted of an initial denaturation step at $94{ }^{\circ} \mathrm{C}$ for $1 \mathrm{~min}$ followed by 33 cycles of $94{ }^{\circ} \mathrm{C}$ for $30 \mathrm{~s}, 55^{\circ} \mathrm{C}$ for $30 \mathrm{~s}, 68^{\circ} \mathrm{C}$ for $2 \mathrm{~min}$, and a final extension at $68^{\circ} \mathrm{C}$ for $3 \mathrm{~min}$. This amplification generated one fragment of $576 \mathrm{bp}$. The nucleotide sequence of the amplified fragment was determined by cycle sequencing in both directions - a total of three independent amplifications. Sequence determination was performed using the Big Dye Terminator Cycle Sequencing Ready Reactions (PE Applied Biosystems, Foster City, CA, USA) according to manufacturer's instructions and run on an ABI 377 DNA sequencer (PE Applied Biosystems).

To obtain the complete coding sequence of porcine PPAR $\delta, 5^{\prime}$ and $3^{\prime}$ rapid amplification of the cDNA ends (RACE) was performed using the Marathon cDNA amplification kit (Clontech). Poly $\mathrm{A}^{+}$RNA was isolated using the Nucleotrap mRNA purification kit (Clontech). One microgram of Poly $A^{+}$RNA from sow endometrial tissue was reverse-transcribed using the Marathon cDNA synthesis primer. Second strand cDNA was synthesized and a Marathon cDNA adaptor (Clontech) was ligated as recommended by the manufacturer. The $3^{\prime}$ end amplification of porcine PPAR $\delta$ was performed using an upstream primer 5'-ACTACGGAGTCCACGCTTGCGA-3', which corresponds to pig PPAR $\delta$ cDNA between nucleotides 535 and 556 (GenBank accession no. NM_214152). The 3' RACE generated a single fragment of $1.5 \mathrm{~kb}$.

Table 2 Oligonucleotide primers used for cloning, tissue distribution, and real-time PCR of selected porcine genes.

\begin{tabular}{|c|c|c|c|c|}
\hline Primer name & Primer sequences $\left(5^{\prime}-3^{\prime}\right)^{a}$ & Primer position (nt) & GenBank accession no. & Length (bp) \\
\hline \multicolumn{5}{|l|}{ Cloning } \\
\hline PPARD-F & CAAGGCMTCRGGCTTCCACTA & $518-538$ & NM_214152 & 576 \\
\hline PPARD-R & CTGAAGYTGGGGATGYTCTTG & 1073-1093 & & \\
\hline \multicolumn{5}{|l|}{ Tissue distribution } \\
\hline PPARD-t-F & CCGCATGAAGCTGGAGTACGAG & $587-608$ & NM_214152 & 358 \\
\hline PPARD-t-R & CTGCCACAACGTCTCGATGTCG & 923-944 & & \\
\hline ADD1-t-F & CTCGCAGATCCAGCAGGTC & $700-718$ & AY496867 & 79 \\
\hline ADD1-t-R & TTTCATGGTCGTCAGGAGCA & $759-778$ & & \\
\hline ANGPTL4-t-F & CAGGATGGCTCGGTGGACTT & $70-89$ & AY307772 & 340 \\
\hline ANGPTL4-t-R & TCTTGGCGCAGTTCTTGTCTC & $389-409$ & & \\
\hline \multicolumn{5}{|l|}{ Real-time $P C R$} \\
\hline PPARD-rt-F & CGCATGAAGCTGGAGTACGA & $588-607$ & NM_214152 & 71 \\
\hline PPARD-rt-R & TGGCACTTGTTGCGGTTCT & $640-658$ & & \\
\hline PPARG1-F & GCСАACTCTAAGCCACTAACATACAG & $66-91$ & AJ006756 & 73 \\
\hline PPARG1-R & TGGTCACCTCGCTAAAAGATGA & $117-138$ & & \\
\hline PPARG2-F & TGTTATGGGTGAAACTCTGGGAG & $12-34$ & AF103946 & 78 \\
\hline PPARG2-R & GAAATGTTTGCAGACAGCGTG & $69-89$ & & \\
\hline ANGPTL4-F & TGGCTCGGTGGACTTTAACC & $75-94$ & AY307772 & 66 \\
\hline ANGPTL4-R & TCACCTTTGGGATCTCCGAA & $121-140$ & & \\
\hline Cyclophilin-F & GCACTGGTGGCAAGTCCAT & 219-237 & AY266299 & 71 \\
\hline Cyclophilin-R & AGGACCCGTATGCTTCAGGA & $270-289$ & & \\
\hline
\end{tabular}

$F$, forward; $R$, reverse.

${ }^{a}$ Degenerated primers where $\mathrm{M}=\mathrm{A}$ or $\mathrm{C}, \mathrm{R}=\mathrm{A}$ or $\mathrm{G}, \mathrm{Y}=\mathrm{C}$ or $\mathrm{T}$. 
The $5^{\prime}$ end of pig PPAR $\delta$ was amplified using a pig specific downstream primer 5'-CTGCCACAACGTCTCGATGTCG-3', which hybridizes with nucleotides 923 to 944 of the pig PPAR $\delta$ cDNA sequence (GenBank accession no. NM_214152). The amplified $5^{\prime}$ end generated a single fragment of $1 \mathrm{~kb}$. Both $5^{\prime}$ and $3^{\prime}$ end fragments were sequenced as described above and were assembled using the AutoAssembler 2.0 software (PE Applied Biosystems) to determine the complete porcine specific PPAR $\delta$ coding sequence. PPAR $\delta$ sequence features were found using NCBI Conserved Domain Search (Marchler-Bauer et al. 2003).

\section{Tissue distribution of porcine PPAR $\delta$, ANGPTL4, and ADD1 mRNA}

Amplifications of PPAR $\delta$, ADD1, and ANGPTL4 cDNAs were performed in various pig tissues using primers described in Table 2. Total RNA extraction and cDNA synthesis were performed as described above. PCR amplifications were performed in a $100 \mu \mathrm{l}$ total volume which contained a $2 \mu \mathrm{l}$ aliquot of the reverse transcriptase product, $150 \mathrm{nM}$ of forward and reverse primers, $200 \mu \mathrm{M}$ dNTPs, $1 \mathrm{mM} \mathrm{MgCl}$ (0.8 mM for ADD1), and 0.5 unit of Taq polymerase in $1 \times$ Taq polymerase buffer (Amersham Pharmacia Biotech). The PCR profile consisted of an initial denaturation step at $94{ }^{\circ} \mathrm{C}$ for $2 \mathrm{~min}$, followed by 35 cycles (36 for ADD1) of denaturing at $94{ }^{\circ} \mathrm{C}$ for $1 \mathrm{~min}$, annealing at $69^{\circ} \mathrm{C}\left(61^{\circ} \mathrm{C}\right.$ for ADD1 and ANGPTL4) for $1 \mathrm{~min}$, extension at $72{ }^{\circ} \mathrm{C}$ for $1 \mathrm{~min}$, and a final extension at $72{ }^{\circ} \mathrm{C}$ for $5 \mathrm{~min}$. Pig cyclophilin amplification using forward 5'-ACCGTCTTCTTCGACATCGC- $3^{\prime}$ and reverse 5'-CTTGCTGGTCTTGCCATTCC-3' primers, which correspond to nucleotides $17-36$ and $447-466$ of the pig cyclophilin sequence (GenBank accession no. AY266299), was also performed on the same cDNAs as an internal control for variations in cDNA synthesis. The $100 \mu \mathrm{l}$ PCR reaction mixture contained a $2 \mu \mathrm{l}$ aliquot of the reverse transcriptase product, $150 \mathrm{nM}$ of forward and reverse primers, $200 \mu \mathrm{M}$ dNTPs, $1.0 \mathrm{mM} \mathrm{MgCl}_{2}$, and 0.5 unit of Taq polymerase in $1 \times$ Taq polymerase buffer (Amersham Pharmacia Biotech). The PCR profile used was the same as that described above for PPAR $\delta$, with the exception of the annealing temperature, which was $60^{\circ} \mathrm{C}$. Amplified PCR fragments were electrophoresed on a $1.5 \%$ agarose gel (3\% for ADD1) and stained with ethidium bromide. These fragments were single pass sequenced as described above to confirm their identity. Pictures of the resulting gels were taken with Polaroid positive/negative film (\#55). Negatives from Polaroid positive/negative photos were then scanned using an Imaging Densitometer (Model GS-670; BioRad). PCR amplifications were repeated in duplicate using two different tissue samples from the same animal.

\section{Quantitative measurements of mRNA levels in endometrial tissues}

Endometrial tissues at embryo attachment (groups 1, 2, and 3) and between attachment sites (group 2) were analyzed for PPAR $\delta, \operatorname{PPAR} \gamma 1, \mathrm{PPAR} \gamma 2, \mathrm{ADD} 1$, and ANGPTL4 mRNA levels using real-time PCR amplifications. Gene-specific primers (Table 2) were designed and selected using the Primer Express Software (PE Applied BioSystem). Primers used for ADD1 are the same as those used for tissue distribution. Real-time PCR amplifications were performed in $25 \mu \mathrm{l}$ reaction volume consisting of $50 \mathrm{nM}$ of forward and reverse primer, $1 \mu \mathrm{l}$ of CDNA, $0.25 \mu$ l AmpErase (PE Applied BioSystems) and $1 \times$ SYBR Green Master Mix (PE Applied BioSystems). Cycling conditions were $2 \mathrm{~min}$ at $50{ }^{\circ} \mathrm{C}$, followed by $10 \mathrm{~min}$ at $95^{\circ} \mathrm{C}$. Then, 40 cycles of $15 \mathrm{~s}$ at $95^{\circ} \mathrm{C}$ and $1 \mathrm{~min}$ at $60^{\circ} \mathrm{C}$ were performed. Amplification, detection, and analysis were performed with an $A B I$ Prism 7700 Sequence Detector (PE Applied BioSystems). Samples were normalised using the housekeeping gene cyclophilin (Table 2). Reaction mixtures contained $50 \mathrm{nM}$ of forward and $900 \mathrm{nM}$ of reverse primers. Real-time PCR cycling conditions were the same as described above. All realtime PCR reactions were performed in triplicate and standard curves were established in duplicate for each gene. Target genes and cyclophilin amplifications were run in separate assays. A pool of endometrial cDNA was used to create a standard curve for quantification of the transcripts using the relative standard curve method as described by Applied Biosystems (User Bulletin \#2 1997). Standard curve arbitrary units were set at 1 for the undiluted cDNA pool and dilutions of $0.75,0.50,0.25$, $0.10,0.05,0.025$, and 0.005 were then performed. For each experimental sample, the amount of target gene mRNA relative to endogenous cyclophilin was determined from their respective standard curves. Relative quantity ratios were obtained by dividing the relative quantity units of target genes by those of cyclophilin. Mean values from triplicates were then used to perform statistical analyses. The specificity of the amplified fragments was verified on a $3.5 \%$ agarose gel and with melting curve analysis using the Dissociation Curves v1.0 software (PE Applied BioSystems).

\section{Immunohistochemical analysis}

Uterine tissues were fixed in $4 \%$ paraformaldehyde, $0.1 \mathrm{M}$ sodium cacodylate and kept in a $0.4 \%$ paraformaldehyde solution at $4{ }^{\circ} \mathrm{C}$ until embedded in paraffin. Endogenous peroxidase activity was quenched by incubating slides for $30 \mathrm{~min}$ in methanol containing $0.3 \%$ hydrogen peroxide, and sections were boiled for $15 \mathrm{~min}$ in $0.01 \mathrm{M}$ citrate buffer, $\mathrm{pH} 6.0$ for antigen retrieval. Non-specific protein binding was blocked by incubating sections in Tris-buffered saline (TBS) containing $10 \%$ normal goat serum (Jackson Immuno Research 
Laboratories, West Grove, PA, USA) for $45 \mathrm{~min}$ at room temperature. Tissues were then incubated overnight at $4{ }^{\circ} \mathrm{C}$ in a 1:50 dilution in TBS of either rabbit anti-human PPAR $\gamma$ or PPAR $\delta$ polyclonal antiserum (Santa Cruz Biotechnology, Santa Cruz, CA, USA). Slides were washed twice $(5 \mathrm{~min})$ at room temperature. Primary antibody was detected using the Vectastain ABC kit (Vector Laboratories, Burlingame, CA, USA), which includes a biotinylated goat anti-rabbit secondary antibody at a concentration of $10 \mu \mathrm{g} / \mathrm{ml}$. The Nova Red substrate kit (Vector Laboratories) detected peroxidase activity in the form of a red precipitate. Sections were counterstained with hematoxylin. Control sections were subjected to the same procedure, except that rabbit antihuman PPARS and PPAR $\gamma$ antibodies were omitted.

\section{Statistical analyses}

Relative quantification of mRNA levels was performed according to the standard curve method described by Applied Biosystems (User Bulletin no. 2, PE Applied Biosystem 1997). Group 1 means were analyzed using a one-way ANOVA on two treatment groups (multiparous vs nulliparous). Groups 2 and 3 means were analyzed by all pair-wise multiple comparison procedures (Tukey test) or by a two-way ANOVA (full factorial on sampling site and day of pregnancy) where pertinent. Data were analyzed using SAS (SAS Institute, Inc., Cary, NC, USA, version 8.1) and results are presented as least square means of mRNA relative abundance \pm s.E.M. Statistical significance was set at $P<0.05$.

\section{Results \\ Cloning and sequence analysis of porcine PPARS cDNA}

Using RT-PCR and RACE on total RNA isolated from porcine endometrial tissue, the complete cDNA coding sequence for porcine PPAR $\delta$ was obtained (GenBank accession no. NM_214152). Analysis of the porcine PPAR $\delta$ nucleotide sequence indicated it to be 91.7, 88.1, and $88.8 \%$ identical to the human, rat, and mouse sequences, respectively, with a predicted protein sequence length of 441 amino acids. Analysis of the deduced PPAR $\delta$ amino acid sequence (Fig. 1) showed a 95,89 , and $90 \%$ homology with human, rat, and mouse sequences respectively. Multiple alignments revealed that the DNA-binding and ligand-binding domains, characteristic of the nuclear receptors, are also well conserved in the pig PPAR $\delta$ protein relative to other species (Desvergne \& Wahli 1999).

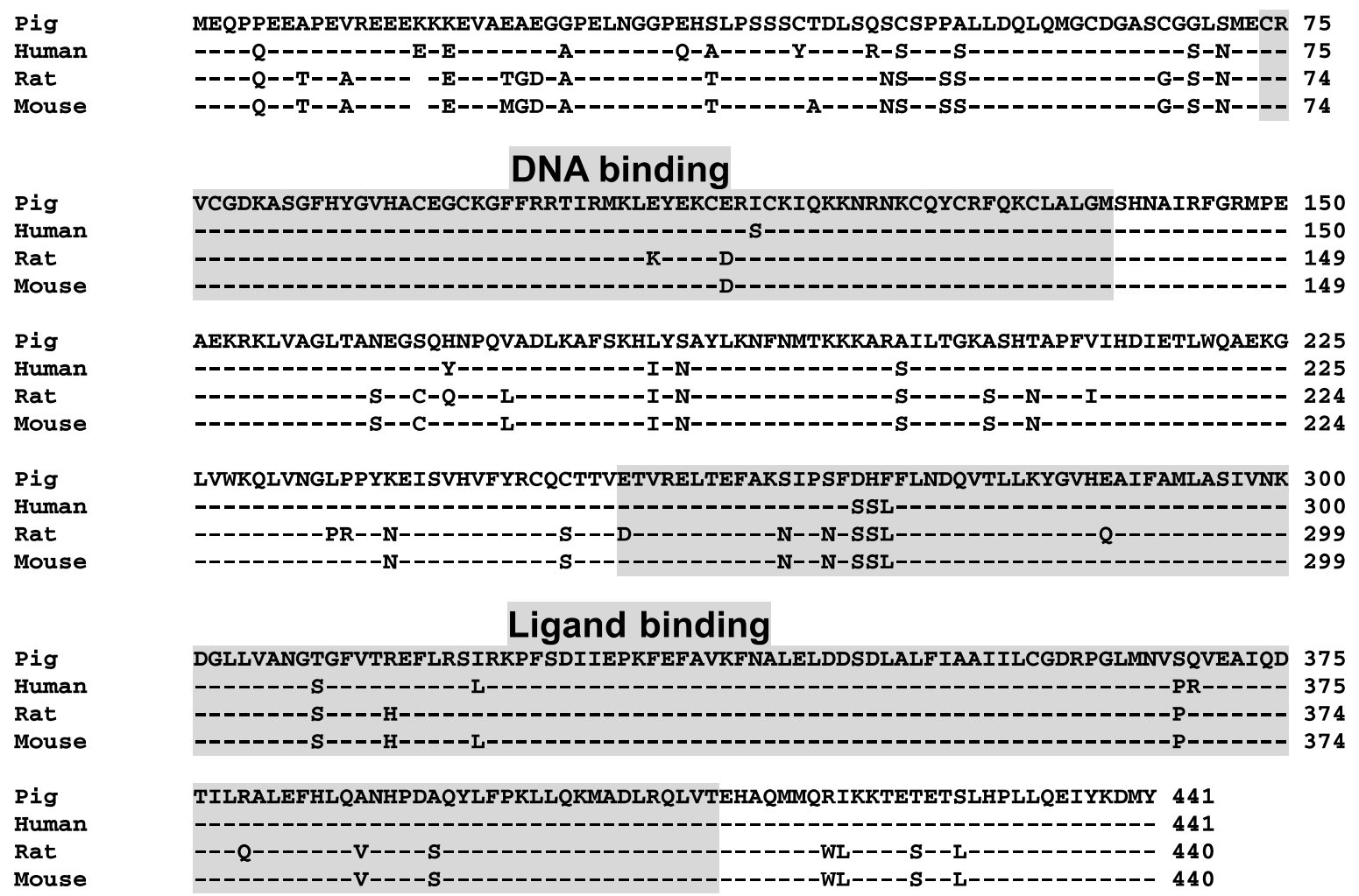

Figure 1 Deduced amino acid sequence of pig PPARס. Alignment of the predicted amino acid sequences of pig (NM_214152), human (AY442342), rat (U75918), and mouse (NM_011145) PPARס. Residues identical to the pig sequence are indicated by a hyphen. The DNA binding (C4 zinc finger) and ligand-binding domains of nuclear hormone receptors are shaded. 


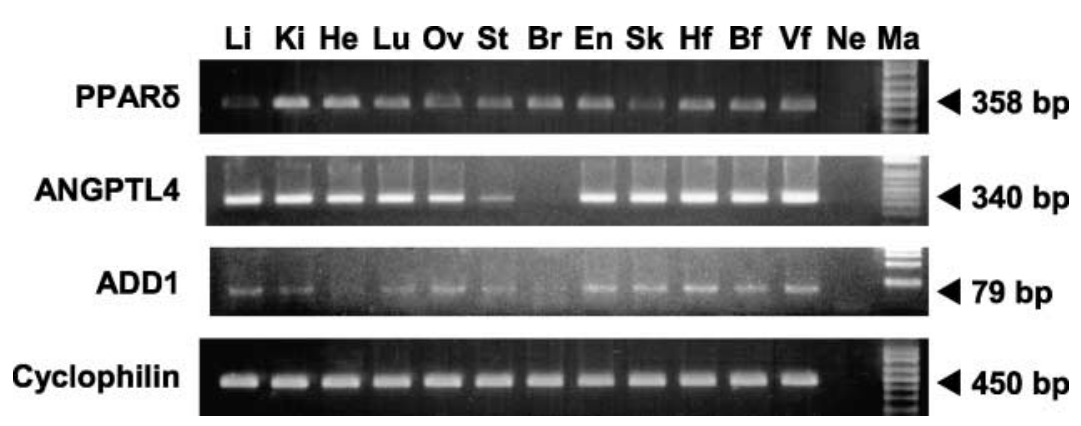

Figure 2 RT-PCR analysis of PPAR $\delta$, ANGPTL4, and ADD1 mRNA in various tissues collected from an adult Duroc $X$ Yorkshire-Landrace sow. Li, liver; Ki, kidney; $\mathrm{He}$, heart; Lu, lung; Ov, ovary; St, stomach; $\mathrm{Br}$, brain cortex; En, endometrium; Sk, skeletal muscle; Hf, ham subcutaneous fat; $\mathrm{Bf}$, back subcutaneous fat; $\mathrm{Vf}$, visceral fat; $\mathrm{Ne}$, negative control without cDNA; Ma, molecular marker. Expected fragment length (bp) is indicated on the right. Equal amounts of PCR products were loaded per lane as adjusted by cyclophilin housekeeping gene.

\section{Expression of PPAR $\delta$, ANGPTL4, and ADD1 transcripts in porcine tissues}

Relative abundance of PPAR $\delta$, ANGPTL4, and ADD1 mRNA were assessed in various tissues from an adult sow. A single amplified fragment of $358 \mathrm{bp}$ was detected for PPAR $\delta$ in all tissues tested (Fig. 2). ANGPTL4 amplification generated a single fragment of $340 \mathrm{bp}$, which was expressed in all tissues with the exception of the cerebral cortex where it was undetectable. Finally, a single ADD1 fragment of $79 \mathrm{bp}$ was amplified in all tissues but very faint amplifications were obtained in the heart and brain cortex tissues.

\section{PPAR $\delta$ and PPAR $\gamma$ localization during the peri-implantation period}

Immunostaining detected PPAR $\delta$ and PPAR $\gamma$ in nuclei of pig endometrial cells while both were absent in the myometrium. On day 15 of pregnancy, PPAR $\delta$ staining was observed at attachment sites in the luminal and glandular epithelium and minor expression of PPAR $\delta$ was present in the subepithelial stroma (Fig. $3 \mathrm{~A}$ and B). Between attachment sites, there was PPAR $\delta$ immunoreactivity in the luminal and glandular epithelium, but none in stromal cells (Fig. 3C and D). On day 25 of pregnancy, PPAR $\delta$ protein was found in trophoblast cells (Fig. 3E) but, at the implantation sites, only weak expression was detected in the luminal epithelium and it was absent from the glandular epithelium and stroma (Fig. 3E and F). Between attachment sites, a stronger signal was detected for PPAR $\delta$ in the luminal epithelium and staining was detected in the glands located in close proximity to the luminal epithelium (Fig. 3G). No signal could be detected in glands adjacent to the myometrium (Fig. 3H). Day 15 cycling sows displayed PPAR $\delta$ immunostaining in luminal and glandular epithelium but we were unable to detect a signal in stromal cells (Fig. 3I and J).

The antibody employed interacted with both isoforms of PPAR $\gamma$, and thus it was not possible to distinguish between these subtypes. Readily identifiable immunostaining was present in endometrial luminal and glandular epithelium at day 15 in cycling sows (Fig. $4 \mathrm{I}$ and $\mathrm{J}$ ) and pregnant sows both between (Fig. 4C and D) and in attachment sites (Fig. 4A and B). Faint PPAR $\gamma$ staining was detected in subepithelial stroma at the implantation sites only (Fig. 4A). On day 25 of pregnancy, PPAR $\gamma$ protein was detected in trophoblast cells (Fig. 4E), in cells of the luminal epithelium at (Fig. 4E) and between (Fig. 4G) attachment sites. The glandular epithelium of day 25 pregnant sows showed no PPAR $\gamma$ immunostaining at attachment sites (Fig. 4F) and only weak signal between attachment sites (Fig. 4H). No staining was evident in stromal cells at this time (Fig. $4 \mathrm{E}-\mathrm{H}$ ).

\section{Effect of parity on mRNA abundance of selected genes in endometrial tissues}

Using real-time PCR, porcine PPAR $\delta$, PPAR $\gamma$ 1, PPAR $\gamma 2$, ANGPTL4, and ADD1 mRNA levels were quantified in endometrial tissue collected at attachment sites from sow group 1. Levels of PPAR $\delta$ mRNA were higher in multiparous than in YLn sows (Fig. 5A; $P<0.01$ ). Significant parity effects were also observed for ANGPTL4 (Fig. 5D; $P<0.01$ ) and ADD1 (Fig. 5E; $P<0.05)$ mRNA levels, where they were found to be higher in YL compared with the nulliparous sows. There were no significant parity effects for porcine PPAR $\gamma 1$ and PPAR $\gamma 2$ mRNA levels (Fig. 5B and C; $P>0.05$ ).

\section{Effect of the site of endometrial tissue sampling}

To determine whether porcine PPAR $\delta$, PPAR $\gamma 1$, PPAR $\gamma 2$, ANGPTL4, and ADD1 mRNA levels could be modulated according to the site of endometrial tissue sampling, tissues were collected at and between embryo attachment sites. Expression levels of PPAR $\delta, P P A R \gamma 1$, and ANGPTL4 mRNAs were higher between sites relative to attachment sites and this effect was significant at both day 15 and day 25 of pregnancy (Fig. 6A, B, and D; $P<0.05$ ). In contrast, there was no effect of endometrial tissue site sampling on PPAR $\gamma 2$ and ADD1 mRNA levels at either day 15 or day 25 of pregnancy (Fig. 6C and E; $P>0.05$ ).

\section{Effect of the day of pregnancy and pregnancy status on selected gene mRNA levels}

The effect of the day of pregnancy and pregnancy status on expression levels of PPARס, PPAR $\gamma 1$, PPAR $\gamma 2$, ANGPTL4, 

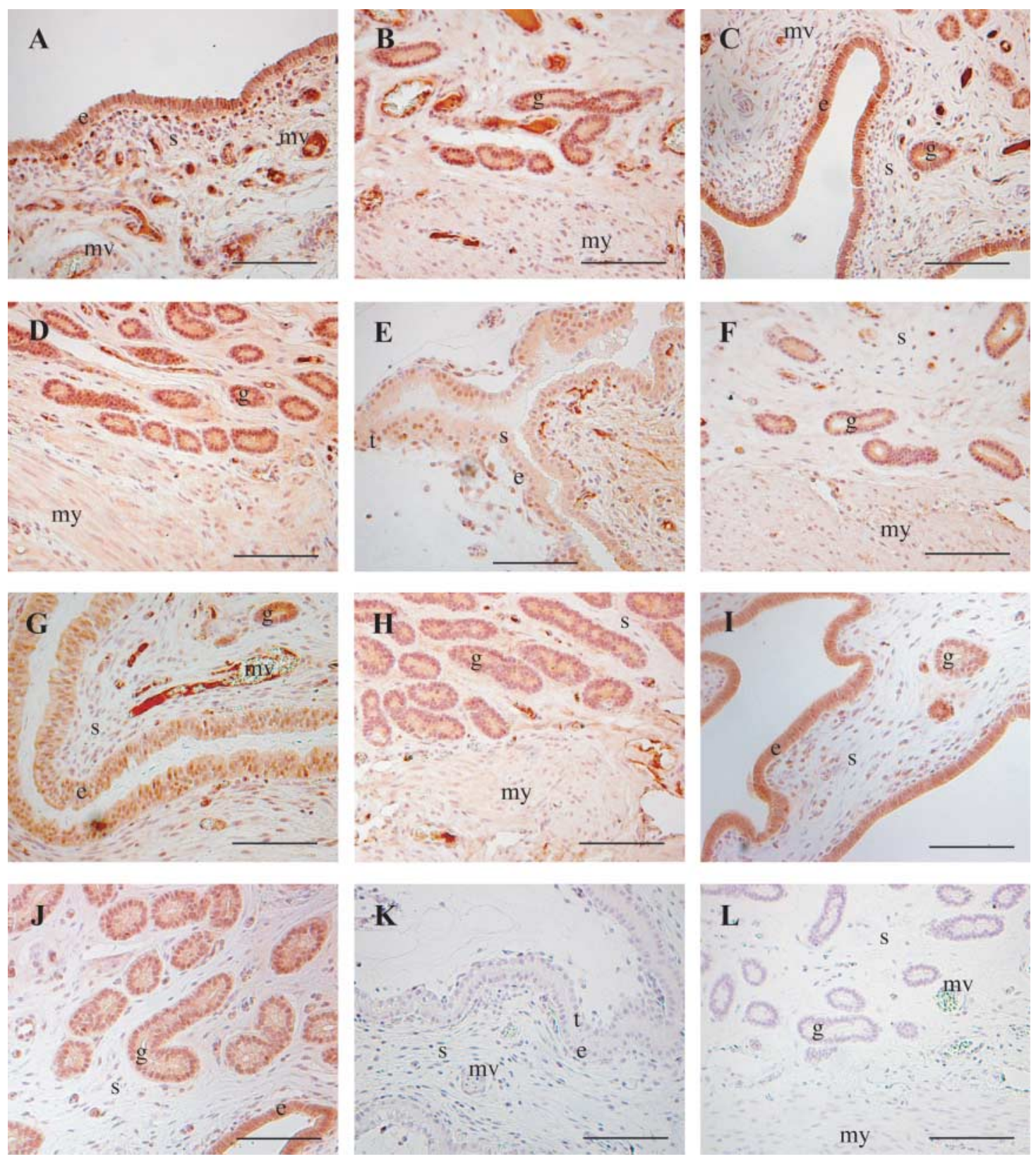

Figure 3 Immunohistochemical localization of PPAR $\delta$ in pig uterus. (A) and (B) Attachment sites of a day 15 pregnant sow; PPAR $\delta$ protein is localized in luminal and glandular epithelium; minor staining is detected in the first cell layer of subepithelial stroma. (C) and (D) Tissue from between attachment sites of a day 15 pregnant sow; PPAR $\delta$ is detected in luminal and glandular epithelium. (E) and (F) Attachment sites of a day 25 pregnant sow; PPAR $\delta$ immunostaining present in trophoblast and weak signal is detected in the luminal epithelium; PPAR $\delta$ protein is absent from stroma and glands. $(\mathrm{G})$ and $(\mathrm{H})$ Between attachment sites of a day 25 pregnant sow; PPAR $\delta$ is observed in the luminal epithelium and in glands located near the luminal epithelium; no signal detected in glands adjacent to the myometrium. (I) and (J) Day 15 cycling sow; immunostaining is present in luminal and glandular epithelium. (K) and (L) Negative controls for localization. e, luminal epithelium; g, glandular epithelium; s, stroma; my, myometrium; mv, maternal blood vessel; t, trophoblast. Bars $=80 \mu \mathrm{m}$.

and ADD1 mRNAs was studied in Duroc $\times$ YorkshireLandrace (group 2) and in Meishan-Landrace (group 3) sows. In the Meishan-Landrace group, the expression level of PPAR $\delta$ mRNA was higher in day 15 cycling sows compared with day $15(P<0.05)$ pregnant sows (Fig. 7A). In both groups 2 and 3, there were no significant differences in PPAR $\delta$ mRNA levels between day 15 and day 25 pregnant sows (Figs 6A and 7A; $P>0.05)$. PPAR $\gamma 1 \mathrm{mRNA}$ levels were higher at day 25 than at day 15 of pregnancy for both group 2 (Fig. 6B, $P<0.05$ ) and group 3 (Fig. $7 \mathrm{~B}, P<0.01$ ) sows, but there was no significant difference of PPAR $\gamma 1$ mRNA levels between day 15 cycling sows and day 15 pregnant sows (Fig. 7B; $P>0.05$ ). There were no effects of the day of 

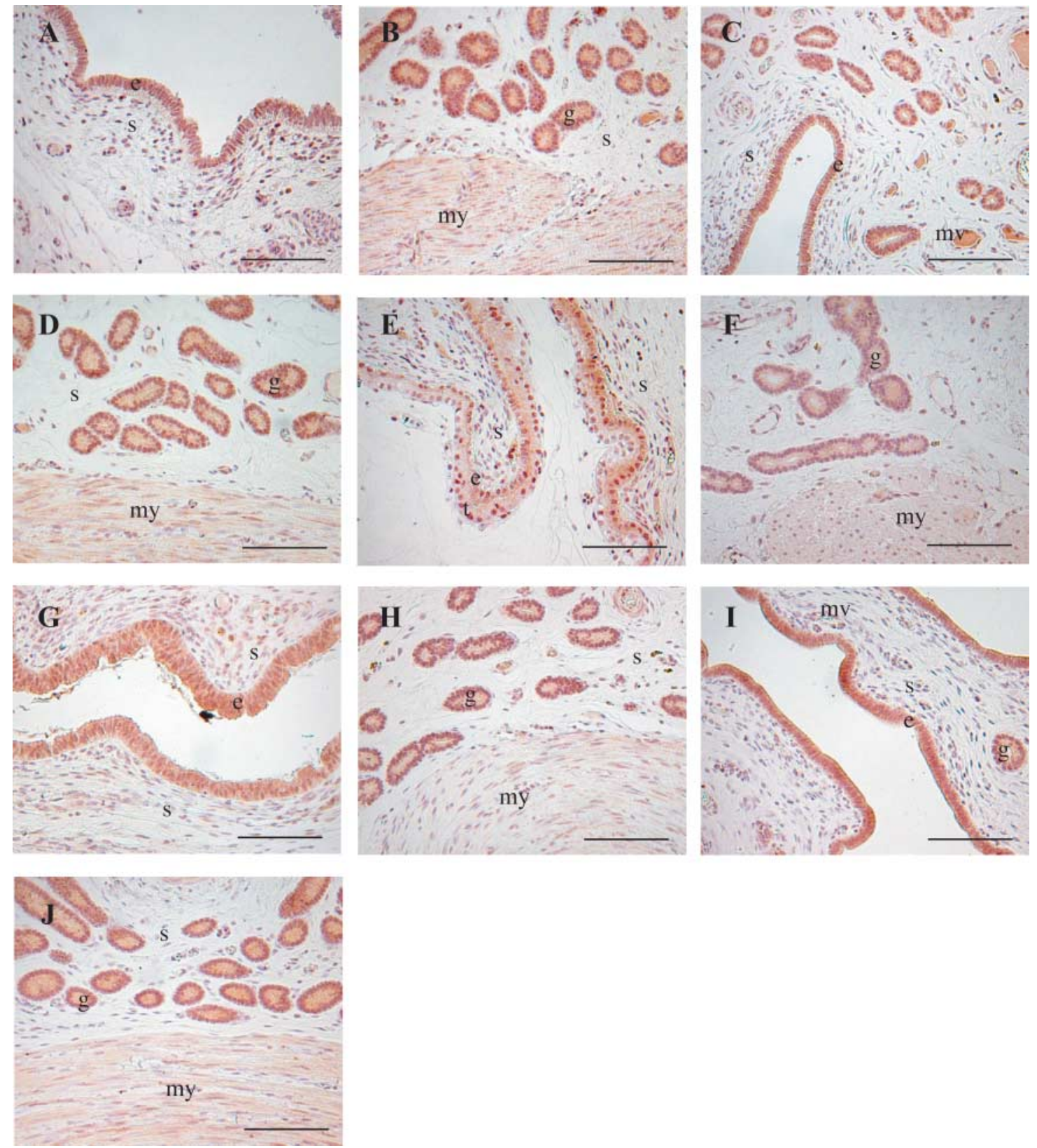

Figure 4 Immunohistochemical localization of PPAR $\gamma$ in pig uterus. (A) and (B) Attachment sites of a day 15 pregnant sow; PPAR $\gamma$ is detected in luminal and glandular epithelium; faint staining is also detected in subepithelial stroma. (C) and (D) Between attachment sites of a day 15 pregnant sow; immunostaining is observed in luminal and glandular epithelium. (E) and (F) At attachment sites of a day 25 pregnant sow;

PPAR $\gamma$ protein is detected in trophoblast cells and in luminal epithelium with no immunostaining in glands. (G) and (H) Between attachments sites of a day 25 pregnant sow; PPAR $\gamma$ staining in luminal epithelium cells and weak signal in glands. (I) and (J) Day 15 cycling sow; PPAR $\gamma$ immunoreactivity is detected in both the luminal and glandular epithelium. e, luminal epithelium; g, glandular epithelium; s, stroma; my, myometrium; mv, maternal blood vessel; $\mathrm{t}$, trophoblast. Bars $=80 \mu \mathrm{m}$.

pregnancy or pregnancy status on PPAR $\gamma 2$, ANGPTL4, and ADD1 mRNA levels in endometrial tissue for both groups 2 and 3 (Fig. 6C-E and Fig. 7C-E; $P>0.05$ ).

\section{Discussion}

To our knowledge, this is the first report of the cloning and characterization of pig PPAR $\delta$ and the first to study
mRNA and protein expression of PPARs in pig endometrial tissues. The complete coding sequence of the porcine PPAR $\delta$ was generated by RT-PCR and RACE using RNA from endometrial tissue as the template. A multiple sequence alignment of porcine PPAR $\delta$ protein with its human, rat, and mouse ortholog shows that the 1-71 amino acids $\mathrm{N}$-terminal extension is the least conserved region with 10 non-conserved amino acids 

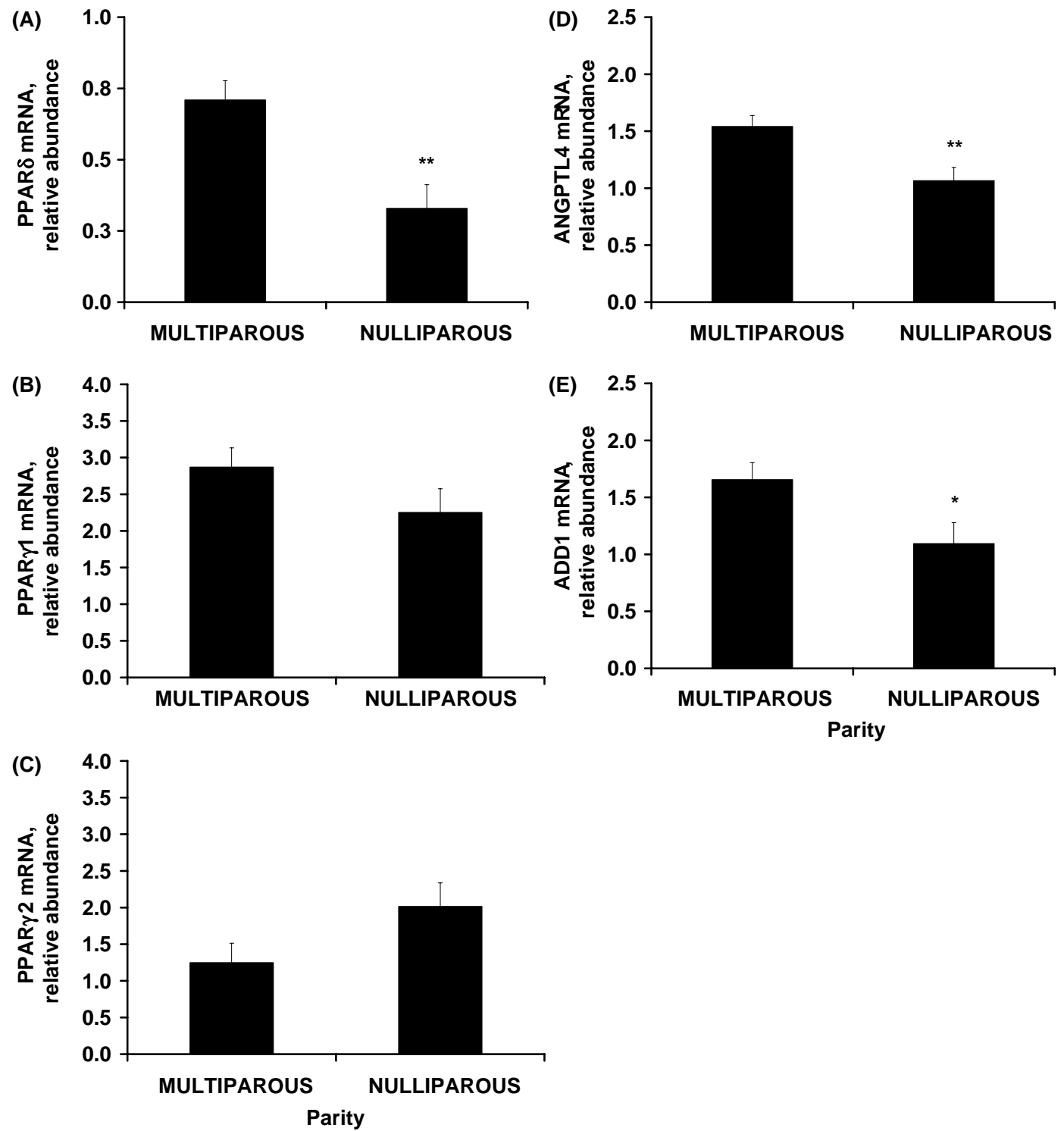

Figure 5 Parity effects on relative expression of PPARס (A), PPAR $\gamma 1$ (B), PPAR $\gamma 2$ (C), ANGPTL4 (D), and ADD1 (E) mRNA in endometrial tissue from day 25 pregnant Yorkshire-Landrace sows. Data are ratios of selected genes relative mRNA levels normalized to cyclophilin housekeeping gene mRNA levels. Each bar represents least square means \pm s.E.M. ${ }^{*} P<0.05 ;{ }^{* *} P<0.01$.

relative to the human PPAR $\delta$ protein sequence. In contrast, the DNA-binding domain is the most conserved region with only one non-conserved amino acid relative to the human PPAR $\delta$ protein sequence. This domain is also known to be the most conserved domain among the nuclear receptor superfamily (Desvergne \& Wahli 1999). The porcine PPAR $\delta$ ligand-binding domain shows a seven amino-acid difference from its human counterpart. This species discrepancy may have functional relevance to the ability of porcine PPAR $\delta$ to bind ligands differentially, as it was previously demonstrated that PPAR $\alpha$ isotypes from Xenopus, mouse, and human respond differentially to the PPAR $\alpha$ ligands Wy 14,643 and ETYA (Keller et al. 1997).
The wide tissue distribution of porcine PPAR $\delta$ transcript contrasts with the more restricted expression of porcine PPAR $\alpha$ (Sundvold et al. 2001) and PPAR $\gamma$ mRNA (Grindflek et al. 1998). The ubiquitous expression of PPAR $\delta$ mRNA in porcine tissues is in accordance with previous studies in human (Skogsberg et al. 2000), rat (Kliewer et al. 1994, Xing et al. 1995), and mouse (Amri et al. 1995). ADD1 and ANGPTL4 transcripts were detected in pig endometrium and ovaries for the first time, suggesting a putative role for these genes in reproductive tissues. Previous studies have reported that the ANGPTL4 transcript was highly enriched in mouse white and brown adipose tissues and in placenta, whereas a lesser mRNA expression was observed for 

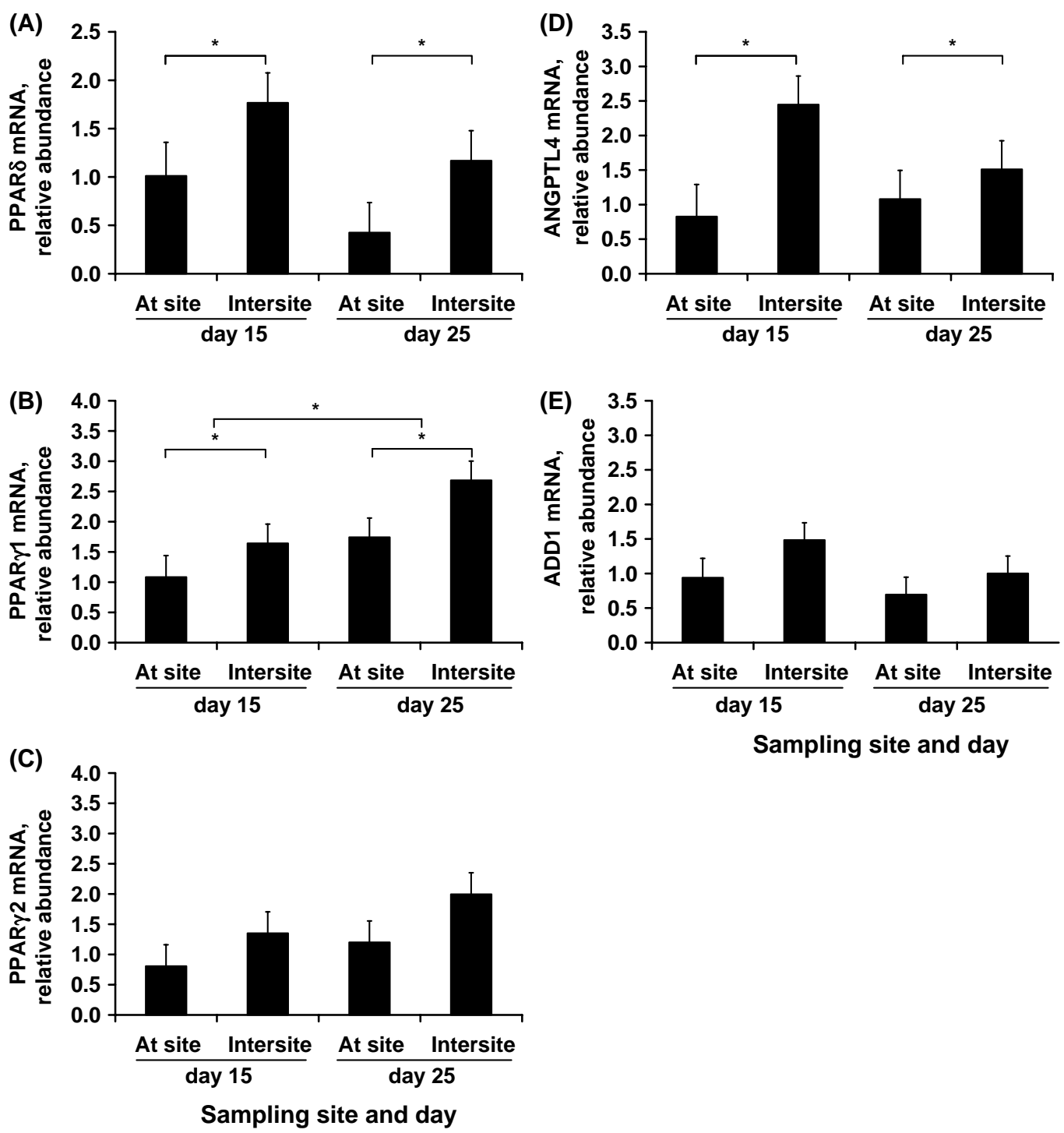

Figure 6 Effects of the day of pregnancy and site of endometrial tissue sampling on relative expression of PPAR $\delta(A)$, PPAR $\gamma 1$ (B), PPAR $\gamma 2$ (C), ANGPTL4 (D), and ADD1 (E) mRNA in endometrial tissue. Sows were from Duroc $\times$ Yorkshire-Landrace breed. Data are ratios of selected genes relative mRNA levels normalized to cyclophilin housekeeping gene mRNA levels. At site, endometrial tissue sample taken at embryo attachment sites; Intersite, endometrial tissue sample taken between attachment sites. Each bar represents least square means \pm s.E.M.; $* P<0.05$.

liver, kidney, heart, and lung (Kersten et al. 2000, Yoon et al. 2000). Interestingly, ANGPTL4 mRNA tends to be more widely and evenly expressed in pig tissues, with the exception of the brain cortex for which no transcript could be detected. As previously reported for human, mouse, and rat tissue distribution studies (Tontonoz et al. 1993, Shimomura et al. 1997, Kim et al. 1998a), we were able to detect ADD1 transcript in pig liver, kidney, lung, ovary, skeletal muscle, adipose tissues, heart, and brain. Our results are in contrast with those of Ding et al. (1999, 2000), who reported ADD1 transcripts to be undetectable in pig kidney and skeletal muscle. In the current study, we used an adult sow to perform tissue distribution analysis, whereas Ding et al. (1999, 2000) used much younger pigs (20-30 kg). Thus, it would be of interest to further study pig ADD1 transcripts in these tissues through musculoskeletal maturation.

PPARs were first recognized as key regulators of adipose differentiation and glucose homeostasis (Desvergne \& Wahli 1999), but accumulating evidence points towards a functional role of the PPARs in the female reproductive tract. For instance, PPAR $\gamma$-null mice exhibit placental defects in trophoblast differentiation and vascular processes (Barak et al. 1999). Further, 90\% of the PPAR $\delta(-/-)$ mouse embryos have severe developmental defects, principally due to placental malformation (Barak et al. 2002). Although, the role of PPARs in fatty acid metabolism has been demonstrated 
(A)

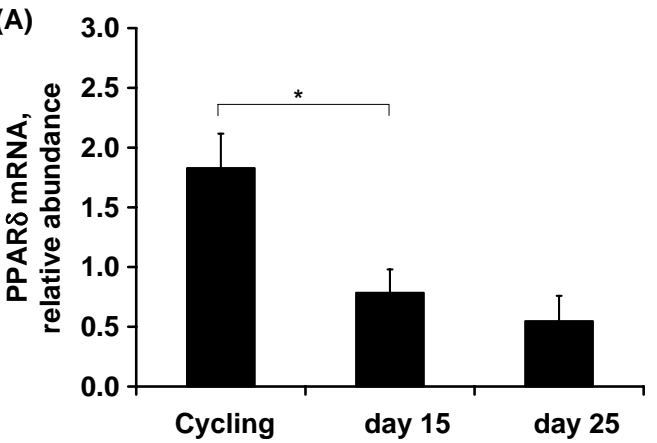

(B)
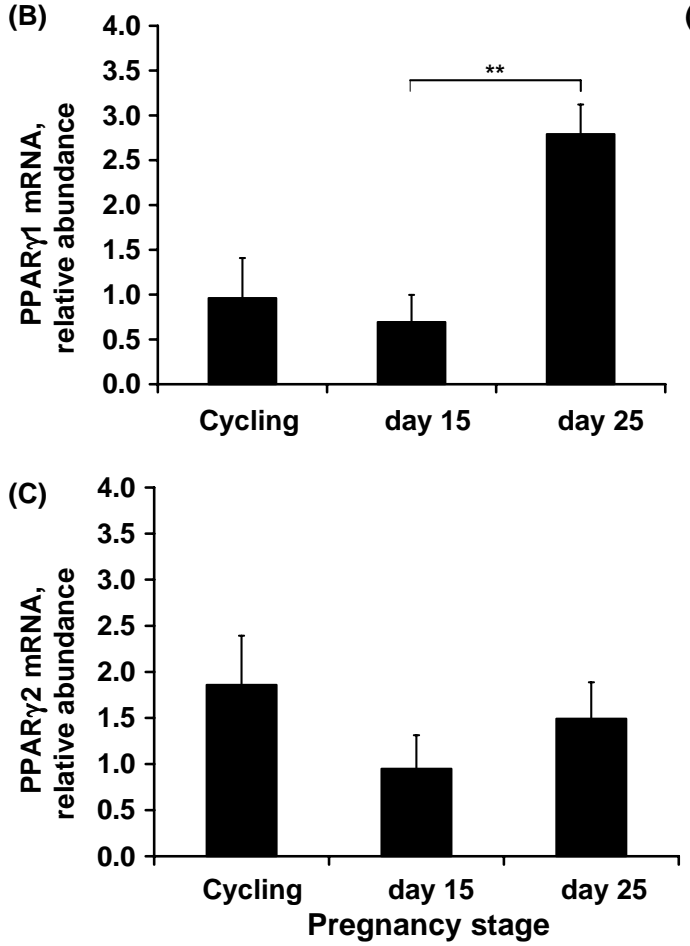
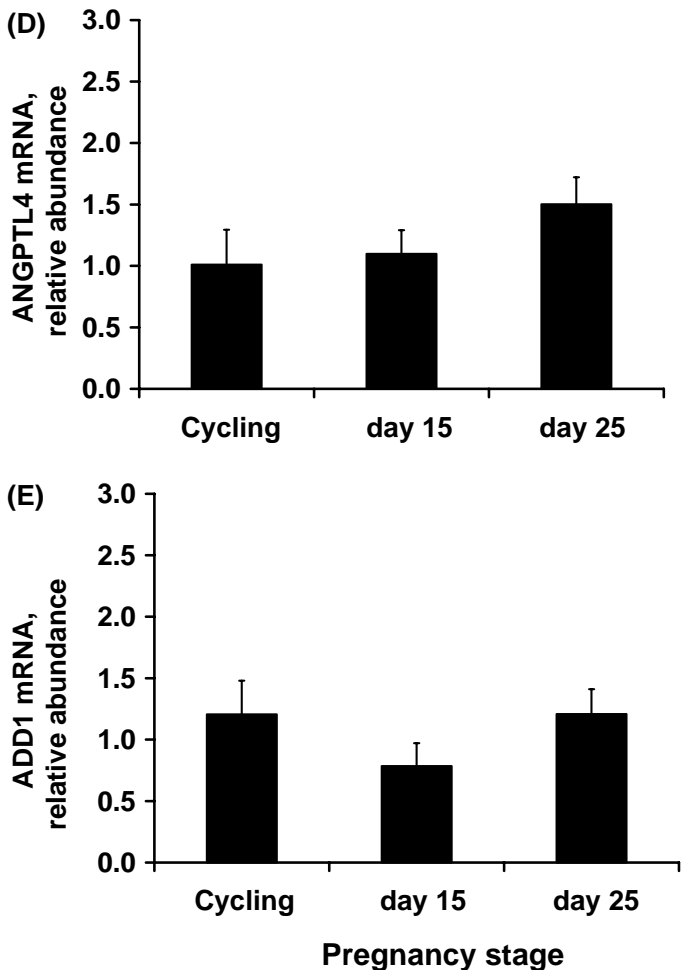

Figure 7 Effects of the day of pregnancy and pregnancy status on relative expression of PPAR $\delta(A), \operatorname{PPAR} \gamma 1$ (B), PPAR $\gamma 2$ (C), ANGPTL4 (D), and ADD1 (E) mRNA in endometrial tissue of Meishan-Landrace sows at day 15 of the estrous cycle (cycling) and at day 15 or day 25 of pregnancy. Data are ratios of selected genes relative mRNA levels normalized to cyclophilin housekeeping gene mRNA levels. Each bar represents least square means \pm S.E.M.; $* P<0.05 ; * * P<0.01$.

in pigs (Grindflek et al. 1998, Sundvold et al. 2001), no studies have yet reported a possible involvement of these receptors in pig pregnancy. In the current study, the presence of PPAR $\delta$ and $\gamma$ transcripts and proteins in pig endometrium, along with modulation of their mRNA abundance according to the parity, pregnancy stage, and site of endometrial tissue sampling, suggest a possible role of these PPARs in early pig gestation. We have shown by immunohistochemistry that PPAR $\delta$ and $\gamma$ proteins are mainly localized in epithelial and glandular cells of the pig endometrium. The principal difference between the PPAR $\delta$ and $\gamma$ signals was the decrease or loss of protein expression in endometrial glands at day 25 compared with day 15 of pregnancy. Moreover, the presence of trophoblast was associated with the detection of PPAR $\delta$ and $\gamma$ signals in the subepithelial stroma at attachment but not between sites, and this was only seen in day 15 pregnant sows. Expression of PPAR $\delta$ was also reported in the subluminal stroma at implantation sites in mouse (Lim et al. 1999) and rat (Ding et al. 2003a) uterus, where immunostaining signals were much stronger. Our data suggest that PPAR $\delta$ and $\gamma$ protein-specific expression in subepithelial stroma is stimulated by the presence of trophoblast during the periimplantation period (day 15) since no corresponding signals were detected in cycling or in day 25 pregnant sows. We have also shown that day 25 trophoblast expresses both PPAR $\delta$ and $\gamma$ proteins. Previous reports demonstrated that PPAR $\gamma$ is required for epithelial differentiation of mouse trophoblast (Barak et al. 1999), 
and strong PPAR $\gamma$ immunostaining was also observed in bovine trophectoderm and inner cell mass cells of preattachment embryos (Mohan et al. 2002). PPAR $\delta$ is also a critical mediator of embryo implantation since its deficiency is lethal to over $90 \%$ of mice embryos (Barak et al. 2002). Thus, the presence of PPAR $\delta$ and $\gamma$ immunostaining in endometrial and trophoblast cells suggests that these nuclear receptors play an important role during early pregnancy in sows.

Our results have shown that pig PPAR $\gamma 2$ mRNA levels were not affected by parity, pregnancy stage, or site of endometrial tissue sampling. PPAR $\gamma 2$ is strongly upregulated during adipogenesis (Tontonoz et al. 1994) and is able to completely restore adipogenesis in 3T3-L1 cells in which both PPAR $\gamma 1$ and $\gamma 2$ expression had been abolished, whereas PPAR $\gamma 1$ had no effect (Ren et al. 2002). In contrast, Barak et al. (1999) reported elevated expression of PPAR $\gamma 1$, but not PPAR $\gamma 2$ mRNA, in mouse placenta from embryonic day 8.5 and onwards, thus suggesting a possible role of PPAR $\gamma 1$, but not PPAR $\gamma 2$, during early pregnancy. In accordance with this later study, we see a marked increase of PPAR 1 mRNA, but not of PPAR $\gamma 2$, in endometrial tissues of day 25 compared to day 15 pregnant sows. We could not confirm this difference at the protein level due to lack of isoform-specific antibodies.

Our results also show that PPAR $\gamma 1$ and PPAR $\delta$ mRNA abundance was lower at attachment sites relative to regions between sites, for both day 15 and day 25 pregnant sows. Although the role of PPAR $\gamma$ in early pregnancy is not known in its entirety, recent studies have shown that PPAR $\gamma$ ligands can have anti-angiogenic actions, as demonstrated by the inhibition of endothelial proliferation and differentiation in vitro and suppression of VEGF-induced angiogenesis in vivo (Xin et al. 1999, Panigraphy et al. 2002). It is worth noting that ANGPTL4 mRNA levels were similarly reduced at pig embryo attachment sites in both day 15 and day 25 pregnant sows. ANGPTL4, which is a known downstream target of PPAR $\gamma$, was also reported to inhibit angiogenesis and vascular permeability both in vitro and in vivo (Ito et al. 2003). Thus, a down-regulation of antiangiogenic factors such as PPAR $\gamma 1$ and ANGPTL4 at the sites of attachment may result in increased uterine vascular permeability and angiogenesis, both required for successful trophoblast-endometrial epithelium interaction in pigs. However, an anti-angiogenic role for PPAR $\gamma 1$ and ANGPTL4 in pig early pregnancy remains to be demonstrated, as PPAR $\gamma$ and ANGPTL4 have also been described as potent proangiogenic factors (Yamakawa et al. 2000, Le Jan et al. 2003). The decreased mRNA levels of PPAR $\delta$ at the site of implantation remain to be explained as this receptor has been described as a mediator of cell proliferation and/or angiogenesis at implantation sites in mice (Lim et al. 1999).

The role of PPAR $\delta$ in embryo implantation was demonstrated in COX-2-deficient mice (Lim et al.
1999) where the COX-2-derived prostaglandin $\mathrm{I}_{2}\left(\mathrm{PGI}_{2}\right)$ participates in implantation via the nuclear receptor PPAR $\delta$ in the mouse uterus. In the current study, the lower mRNA abundance of PPAR $\delta$ found in day 15 pregnant sows when compared with day 15 cyclic sows suggests a limited role of PPAR $\delta$ during the periattachment period. Previous studies have reported higher $\mathrm{PGE}_{2}$ in uterine fluid of day 15 pregnant gilts when compared to the day 15 cyclic gilts (Chabot et al. 2004) and higher $\mathrm{PGF}_{2 \alpha}$ and $\mathrm{PGE}_{2}$ levels in uterine flushings of pregnant relative to non-pregnant gilts (Geisert et al. 1982). Thus, the elevated levels of prostaglandins (Chabot et al. 2004) and the lower mRNA abundance of PPAR $\delta$ (current study) in day 15 pregnant sows suggest that PPAR $\delta$ may be of modest significance in the mediation of action of endometrial and conceptus-derived prostaglandins during the attachment period. Alternatively, the higher level of PPAR $\delta$ mRNA found in cyclic sows suggests a putative role for PPAR $\delta$ during the estrous cycle. Thus, it will be of interest to study further the expression of PPAR $\delta$ relative to the expression of COX-2 and of $\mathrm{PGF}_{2 \alpha}$ and $\mathrm{PGE}_{2}$ through the estrous cycle and pregnancy.

In this study, we report lower levels of PPARS, ANGPTL4, and ADD1 mRNA in nulliparous relative to multiparous $Y L$ sows. There are numerous examples of parity-based differences in livestock reproductive performance but evidence of physiological mechanisms to explain them are still lacking. We previously reported larger litter size and a greater number of corpora lutea (CL) in multiparous than in YLn sows (Guay et al. 2001). Moreover, higher uterine content of estradiol-17 $\left(\mathrm{E}_{2}\right)$ along with higher endometrial mRNA levels of COX-2 were found in multiparous sows compared to nulliparous ones (Guay et al. 2004). Interestingly, estrogen treatment can induce PPAR $\delta$ expression in rat glandular epithelium (Ding et al. 2003a) and expression of PPAR $\gamma$ was also induced by $\mathrm{E}_{2}$ in zebrafish hepatocytes (Ibabe et al. 2005). Moreover, Nunez et al. (1997) reported that PPARs are capable of activating estrogen-responsive genes in the CV-1 tumor cell line. Thus, the higher levels of PPAR $\delta$ mRNA found in multiparous sows may be explained by a higher $E_{2}$ uterine content, as previously reported for multiparous sows (Guay et al. 2004).

This is the first report of ANGPTL4 and ADD1 mRNA in endometrial tissue, and the relative elevation of these transcripts in multiparous sows remains to be explained. Adipocyte determination differentiation-dependent factor 1 (ADD1) is an intracellular membrane-bound transcription factor (Golgi and endoplasmic reticulum) that controls the metabolism of cholesterol and fatty acids in animal cells (Wang et al. 1994, Kim \& Spiegelman 1996). Interestingly, it was also reported that ADD1 controls the production of endogenous ligands for PPARr in NIH 3T3 cells (Kim et al. 1998b). The detection of ADD1 transcript in endometrial tissue may illustrate that PPAR ligands are also produced 
endogenously from endometrial cells expressing ADD1. Because ADD1 would provide PPAR ligands, it is not surprising that these transcripts follow the same expression profile in pig endometrial tissue. However, since ADD1 mRNA abundance was affected by neither pregnancy stage nor site of endometrial tissue sampling, we believe that this transcription factor has a limited role in early porcine gestation.

In summary, we have demonstrated that PPAR $\delta$, PPAR $\gamma 1$, and ANGPTL4 mRNA abundance decreases at the embryonic attachment sites in the pig endometrium at both day 15 and day 25 of pregnancy. Modulation of PPAR $\gamma 1$ expression was also observed according to stage of pregnancy. The parity of sows also had effects on PPAR $\delta$, ANGPTL4, and ADD1 transcripts. The mRNA abundance of PPAR $\gamma 2$ was not affected by the site of endometrial tissue sampling, pregnancy stage, or parity of the sows, thus suggesting that the PPAR 2 subtype does not have a major role in porcine pregnancy. Because this study was performed on a limited number of pigs, further work will be needed on a much larger population and at various stages of pregnancy to confirm the current findings. The precise role of PPAR $\delta$, PPAR $\gamma 1$, and ANGPTL4 genes in early pig pregnancy remains to be established, but our findings suggest that they may have key roles in prostaglandins-mediated action on the endometrial tissue.

\section{Acknowledgements}

This work was supported by the National Sciences and Engineering Research Council of Canada Strategic Grant no. 246154 to B M D and M F P, Genetiporc Inc. (St-Bernard, QC, Canada) and Agriculture and Agri-Food Canada. E L is supported by FPPQ fellowship. The authors are grateful to staff of the Swine Complex for animal care and S. Méthot for statistical analysis. Lennoxville Dairy and Swine R\&D Centre contribution no. 884. The authors declare that there is no conflict of interest that would prejudice the impartiality of this scientific work.

\section{References}

Amri E-Z, Bonino F, Ailhaud G, Abumrad NA \& Grimaldi PA 1995 Cloning of a protein that mediates transcriptional effects of fatty acids in preadipocytes. Journal of Biological Chemistry $\mathbf{2 7 0}$ 2367-2371

Asami-Miyagishi R, Iseki S, Usui M, Uchida K, Kubo H \& Morita I 2004 Expression and function of PPARgamma in rat placental development. Biochemical and Biophysical Research Communications 315 497-501.

Barak Y, Nelson MC, Ong ES, Jones YZ, Ruiz-Lozano P, Chien KR, Koder A \& Evans RM 1999 PPAR gamma is required for placental, cardiac, and adipose tissue development. Molecular Cell 4 585595.

Barak Y, Liao D, He W, Ong ES, Nelson MC, Olefsky JM, Boland R \& Evans RM 2002 Effects of peroxisome proliferator-activated receptor delta on placentation, adiposity, and colorectal cancer. PNAS 99 303-308.

Belanger AJ, Lu H, Date T, Liu LX, Vincent KA, Akita GY, Cheng SH, Gregory RJ \& Jiang C 2002 Hypoxia up-regulates expression of peroxisome proliferator-activated receptor gamma angiopoietinrelated gene (PGAR) in cardiomyocytes: role of hypoxia inducible factor 1alpha. Journal of Molecular and Cellular Cardiology 34 765-774.

Canadian Council on Animal Care (CCAC) 1993 2nd edn Guide to the Care and Use of Experimental Animals, vol 1. Ontario, Canada: Canadian Council on Animal Care.

Chabot V, Lambert RD, Laforest JP, St-Jacques S, Matte JJ, Guay F, Palin MF \& Lessard M 2004 Effect of oestrous cycle and early pregnancy on uterine production and expression of immune regulatory factors in gilts. Animal Reproduction Science 81 137-149.

Desvergne B \& Wahli W 1999 Peroxisome proliferator-activated receptors: nuclear control of metabolism. Endocrine Reviews 20 649-688.

Ding ST, McNeel RL \& Mersmann HJ 1999 Expression of porcine adipocyte transcripts: tissue distribution and differentiation in vitro and in vivo. Comparative Biochemistry and Physiology Part B 123 307-318.

Ding ST, Schinckel AP, Weber TE \& Mersmann HJ 2000 Expression of porcine transcription factors and genes related to fatty acid metabolism in different tissues and genetic populations. Journal of Animal Science 78 2127-2134.

Ding NZ, Ma XH, Diao HL, Xu LB \& Yang ZM 2003a Differential expression of peroxisome proliferator-activated receptor delta at implantation sites and in decidual cells of rat uterus. Reproduction 125 817-825.

Ding NZ, Teng CB, Ma H, Ni H, Ma XH, Xu LB \& Yang ZM $2003 b$ Peroxisome proliferator-activated receptor delta expression and regulation in mouse uterus during embryo implantation and decidualization. Molecular Reproduction and Development $\mathbf{6 6}$ 218-224.

Geisert RD, Renegar RH, Thatcher WW, Roberts RM \& Bazer FW 1982 Establishment of pregnancy in the pig: I. Interrelationships between preimplantation development of the pig blastocyst and uterine endometrial secretions. Biology of Reproduction 27 925-939.

Geisert RD, Zavy MT, Moffatt RJ, Blair RM \& Yellin T 1990 Embryonic steroids and the establishment of pregnancy in pigs. Journal of Reproduction and Fertility Supplement 40 293-305.

Grindflek E, Sundvold H, Klungland H \& Lien S 1998 Characterisation of porcine peroxisome proliferator-activated receptors $\gamma 1$ and $\gamma 2$ : detection of breed and age differences in gene expression. Biochemical and Biophysical Research Communications 249 713-718.

Guay F, Palin MF, Matte JJ \& Laforest JP 2001 Effects of breed, parity, and folic acid supplement on the expression of leptin and its receptors' genes in embryonic and endometrial tissues from pigs at day 25 of gestation. Biology of Reproduction 65 921-927.

Guay F, Matte JJ, Girard CL, Palin MF, Giguère A \& Laforest JP 2004 Effect of folic acid plus glycine supplement on uterine prostaglandin and endometrial granulocyte-macrophage colony-stimulating factor expression during early pregnancy in pigs. Theriogenology 61 485-498.

Helliwell RJA, Berry EBE, O'Carroll SJ \& Mitchell MD 2004 Nuclear prostaglandin receptors: role in pregnancy and parturition? Prostaglandins, Leukotrienes and Essential Fatty Acids 70 149-165.

Ibabe A, Herrero A \& Cajaraville MP 2005 Modulation of peroxisome proliferator-activated receptors (PPARs) by PPARalpha- and PPARgamma-specific ligands and by 17 beta-estradiol in isolated zebrafish hepatocytes. Toxicology In Vitro 19 725-735.

Ito Y, Oike Y, Yasunaga K, Hamada K, Miyata K, Matsumoto S, Sugano S, Tanihara H, Masuho Y \& Suda T 2003 Inhibition of angiogenesis and vascular leakiness by angiopoietin-related protein 4. Cancer Research 63 6651-6657.

Keller HJ, Devchand PR, Perroud M \& Wahli W 1997 PPAR $\alpha$ structurefunction relationships derived from species-specific differences in responsiveness to hypolipidemic agents. Biological Chemistry $\mathbf{3 7 8}$ 651-655.

Kersten S, Mandard S, Tan NS, Escher P, Metzger D, Chambon P, Gonzalez FJ, Desvergne B \& Wahli W 2000 Characterization of the 
fasting-induced adipose factor FIAF, a novel peroxisome proliferator-activated receptor target gene. Journal of Biological Chemistry 275 28488-29493.

Kim JB \& Spiegelman BM 1996 ADD1/SREBP1 promotes adipocyte differentiation and gene expression linked to fatty acid metabolism. Genes \& Development 10 1096-1107.

Kim JB, Sarraf P, Wright M, Yao KM, Mueller E, Solanes G, Lowell BB \& Spiegelman BM 1998a Nutritional and insulin regulation of fatty acid synthase and leptin gene expression through ADD1/SREBP1. Journal of Clinical Investigation 101 1-9.

Kim JB, Wright HM, Wright M \& Spiegelman BM 1998b ADD1/SREBP1 activates PPAR $\gamma$ through the production of endogenous ligand. PNAS 95 4333-4337.

Kim I, Kim HG, Kim H, Kim HH, Park SK, Uhm CS, Lee ZH \& Koh GY 2000 Hepatic expression, synthesis and secretion of a novel fibrinogen/angiopoietin-related protein that prevents endothelialcell apoptosis. Biochemical Journal 346 603-610.

Kliewer SA, Forman BM, Blumberg B, Ong ES, Borgmeyer U, Mangelsdorf DJ, Umesono K \& Evans RM 1994 Differential expression and activation of a family of murine peroxisome proliferator-activated receptors. PNAS 91 7355-7359.

Lee SS, Pineau T, Drago J, Lee EJ, Owens JW, Kroetz DL, FernandezSalguero PM, Westphal H \& Gonzalez FJ 1995 Targeted disruption of the alpha isoform of the peroxisome proliferator-activated receptor gene in mice results in abolishment of the pleiotropic effects of peroxisome proliferators. Molecular and Cellular Biology 15 3012-3022.

Le Jan S, Amy C, Cazes A, Monnot C, Lamande N, Favier J, Philippe J, Sibony M, Gasc JM, Corvol P \& Germain S 2003 Angiopoietin-like 4 is a proangiogenic factor produced during ischemia and in conventional renal cell carcinoma. American Journal of Pathology 162 1521-1528.

Lim H, Paria BC, Das SK, Dinchuk JE, Langenbach R, Trzaskos JM \& Dey SK 1997 Multiple female reproductive failures in cyclooxygenase 2-deficient mice. Cell 91 197-208.

Lim H, Gupta RA, Ma WG, Paria BC, Moller DE, Morrow JD, DuBois RN, Trzaskos JM \& Dey SK 1999 Cyclo-oxygenase-2-derived prostacyclin mediates embryo implantation in the mouse via PPARdelta. Genes and Development 13 1561-1574.

Mandard S, Zandbergen F, Tan NS, Escher P, Patsouris D, Koenig W, Kleemann R, Bakker A, Veenman F, Wahli W, Muller M \& Kersten S 2004 The direct peroxisome proliferator-activated receptor target fasting-induced adipose factor (FIAF/PGAR/ANGPTL4) is present in blood plasma as a truncated protein that is increased by fenofibrate treatment. Journal of Biological Chemistry 279 34411-34420.

Marchler-Bauer A, Anderson JB, DeWeese-Scott C, Fedorova ND, Geer LY, He S, Hurwitz DI, Jackson JD, Jacobs AR, Lanczycki CJ, Liebert CA, Liu C, Madej T, Marchler GH, Mazumder R, Nikolskaya AN, Panchenko AR, Rao BS, Shoemaker BA, Simonyan V, Song JS, Thiessen PA, Vasudevan S, Wang Y, Yamashita RA, Yin JJ \& Bryant SH 2003 CDD: a curated Entrez database of conserved domain alignments. Nucleic Acids Research 31 383-387.

Martin G, Schoonjans K, Lefebvre AM, Staels B \& Auwerx J 1997 Coordinate regulation of the expression of the fatty acid transport protein and acyl-CoA synthetase genes by PPARalpha and PPARgamma activators. Journal of Biological Chemistry 272 28210-28217.

Marvin KW, Eykholt RL, Keelan JA, Sato TA \& Mitchell MD 2000 The 15-deoxy-delta(12, 14)-prostaglandin J(2)receptor, peroxisome proliferator activated receptor-gamma (PPARgamma) is expressed in human gestational tissues and is functionally active in JEG3 choriocarcinoma cells. Placenta 21 436-440.

Michalik L, Desvergne B, Dreyer C, Gavillet M, Laurini RN \& Wahli W 2002 PPAR expression and function during vertebrate development. International Journal of Developmental Biology 46 105-114.

Mohan M, Malayer JR, Geiser RD \& Morgan GL 2002 Expression patterns of retinoid $\times$ receptors, retinaldehyde dehydrogenase, and peroxisome proliferators activated receptor gamma in bovine preattachment embryos. Biology of Reproduction 66 692-700.

Nunez SB, Medin JA, Braissant O, Kemp L, Wahli W, Ozato K \& Segars JH 1997 Retinoid $\times$ receptor and peroxisome proliferatoractivated receptor activate an estrogen responsive gene independent of the estrogen receptor. Molecular and Cellular Endocrinology 127 27-40.

Panigrahy D, Singer S, Shen LQ, Butterfield CE, Freedman DA, Chen EJ, Moses MA, Kilroy S, Duensing S, Fletcher C, Fletcher JA, Hlatky L, Hahnfeldt P, Folkman J \& Kaipainen A 2002 PPARgamma ligands inhibit primary tumor growth and metastasis by inhibiting angiogenesis. Journal of Clinical Investigation 110 923-932.

Ren D, Collingwood TN, Rebar EJ, Wolffe AP \& Camp HS 2002 PPARgamma knockdown by engineered transcription factors: exogenous PPARgamma2 but not PPARgamma1 reactivates adipogenesis. Genes and Development 16 27-32.

Rosen ED, Walkey CJ, Puigserver P \& Spiegelman BM 2000 Transcriptional regulation of adipogenesis. Genes and Development 14 1293-1307.

Shimomura L, Shimano H, Horton JD, Goldstein JL \& Brown MS 1997 Differential expression of exons $1 \mathrm{a}$ and $1 \mathrm{c}$ in mRNAs for the sterol regulatory element binding protein-1 in human and mouse organs and cultured cells. Journal of Clinical Investigation 99 838-845.

Skogsberg J, Kannisto K, Roshani L, Gagne E, Hamsten A, Larsson C \& Ehrenborg E 2000 Characterization of the human peroxisome proliferator activated receptor delta gene and its expression. International Journal of Molecular Medicine 6 73-81.

Sundvold H, Grindflek E \& Lien S 2001 Tissue distribution of porcine peroxisome proliferators-activated receptor $\alpha$ : detection of an alternatively spliced mRNA. Gene 273 105-113.

Tontonoz P, Kim JB, Graves RA \& Spiegelman BM 1993 ADD1: a novel helix-loop-helix transcription factor associated with adipocyte determination and differentiation. Molecular and Cellular Biology 13 4753-4759.

Tontonoz P, Hu E \& Spiegelman BM 1994 Stimulation of adipogenesis in fibroblasts by PPAR gamma 2, a lipid-activated transcription factor. Cell 79 1147-1156.

User Bulletin \#2: 1997 ABI PRISM 7700 Sequence Detection System, p 36. Foster City, CA, USA: Applied Biosystems.

Wang X, Sato R, Brown MS, Hua X \& Goldstein JL 1994 SREBP-1, a membrane-bound transcription factor released by sterol-regulated proteolysis. Cell 77 53-62.

Xin X, Yang S, Kowalski J \& Gerritsen ME 1999 Peroxisome proliferatoractivated receptor gamma ligands are potent inhibitors of angiogenesis in vitro and in vivo. Journal of Biological Chemistry 274 9116-9121.

Xing G, Zhang L, Zhang L, Heynen T, Yoshikawa T, Smith M, Weiss S \& Detera-Wadleigh S 1995 Rat PPARס contains a CGG triplet repeat and is prominently expressed in the thalamic nuclei. Biochemical and Biophysical Research Communications 217 1015-1025.

Yamakawa K, Hosoi M, Koyama H, Tanaka S, Fukumoto S, Morii H \& Nishizawa Y 2000 Peroxisome proliferator-activated receptorgamma agonists increase vascular endothelial growth factor expression in human vascular smooth muscle cells. Biochemical and Biophysical Research Communications 271 571-574.

Yoon JC, Chickering TW, Rosen ED, Dussault B, Qin Y, Soukas A, Friedman JM, Holmes WE \& Spiegelman BM 2000 Peroxisome proliferator-activated receptor gamma target gene encoding a novel angiopoietin-related protein associated with adipose differentiation. Molecular and Cellular Biology 20 5343-5349.

Received 24 January 2005

First decision 10 February 2005

Revised manuscript received 28 December 2005

Accepted 7 February 2006 